\title{
JURNAL
}

\section{Pembangkitan pola menggunakan konsep grup kertas dinding}

\author{
Yessica Nataliani, Theophilus Wellem, Ade Iriani \\ Fakultas Teknologi Informasi \\ Universitas Kristen Satya Wacana \\ Jl. O. Notohamidjojo, Salatiga 50711, Indonesia
}

Email :yessica.nataliani@uksw.edu,theophilus.wellem@uksw.edu, ade.iriani@uksw.edu

Received: 18-12-2020

Riwayat artikel:

Revised: 22-02-2021

Accepted: 12-07-2021

\section{Abstract}

Two-dimensional repetitive and symmetrical patterns are found in everyday life, such as in cloth motifs, decorative art, road pavement design, and floor tiles. The repetitive and symmetrical patterns are formed by geometric transformation, which comprises translation, rotation, reflection, and glide reflection. In mathematics, the study of repetitive patterns on a plane, formed by geometric transformations, belongs to the plane symmetry group. This plane symmetry group is often referred to as plane crystallographic group or wallpaper group that comprises 17 known patterns. The purpose of this research is to generate various patterns from a basic pattern by applying the concept from the wallpaper group. Furthermore, this research also identifies four cloth motifs and categorizes them to the wallpaper group. This research was conducted by: (1) determining and creating a basic pattern that will be used to form other patterns, (2) generating 17 patterns from the basic pattern based on the patterns in the wallpaper group, (3) identifying some existing motifs downloaded from the Internet and categorize them to the wallpaper group. The basic pattern used in this research is a spiral pattern. The results obtained from this research are the 17 different spiral motifs as well as the identification of four motifs obtained from the Internet to one of the 17 patterns of wallpaper group.

Keywords: repetitive and symmetrical pattern, wallpaper group, spiral pattern

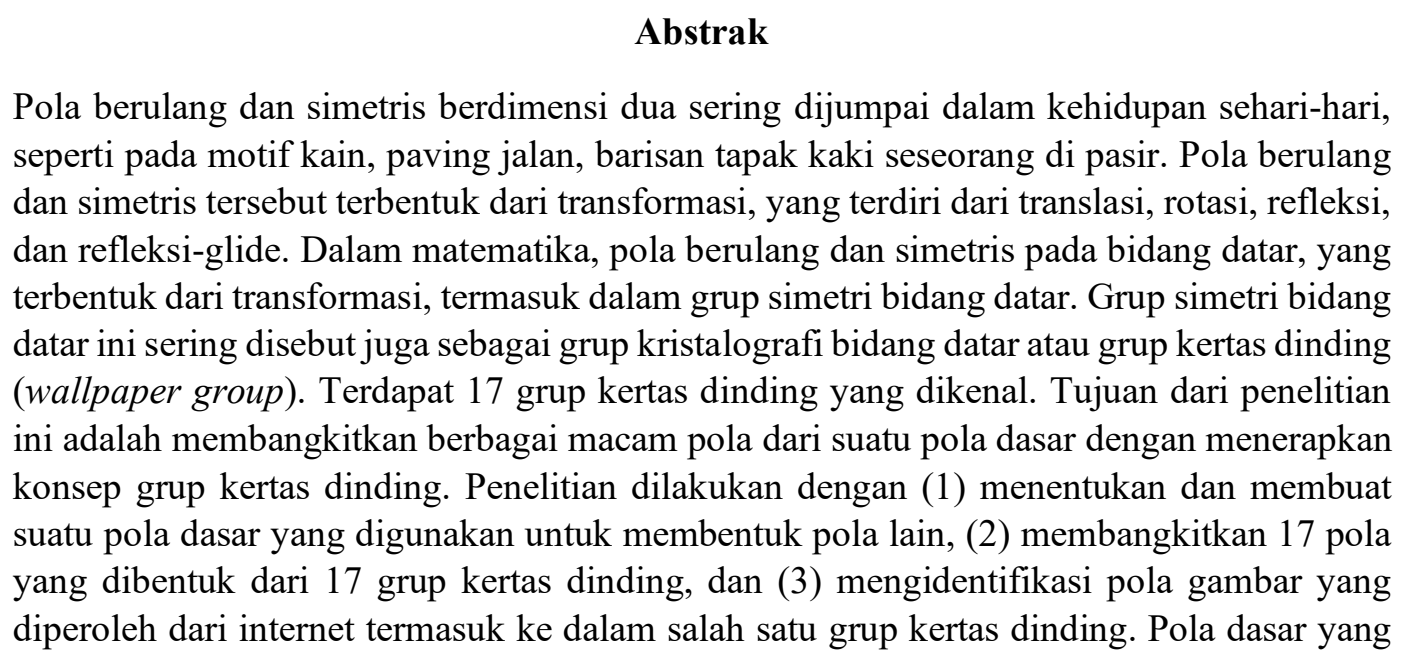


digunakan dalam penelitian ini adalah spiral. Hasil yang didapat berupa 17 motif spiral yang berbeda dan juga empat motif yang diambil dari internet yang dapat dikenali sebagai salah satu pola dari 17 pola grup kertas dinding.

Kata kunci: pola berulang dan simetris, grup kertas dinding, pola spiral

\section{Pendahuluan}

Pola berulang sering ditemui dalam kehidupan sehari-hari, misalnya pada kain, anyaman bambu, paving jalan, ubin, ornamen dinding, dan lain-lain. Pola yang berulang tersebut pada dasarnya dibentuk dari sebuah pola yang ditransformasi sedemikian rupa, sehingga membentuk satu kesatuan pola yang teratur. Sebuah garis yang jika digabungkan dapat membentuk sebuah bujur sangkar, sebuah segitiga sama sisi yang jika digabungkan dapat membentuk sebuah segi enam, sarang lebah yang merupakan gabungan dari segi enam, ataupun barisan tapak kaki manusia yang merupakan gabungan dari dua pasang tapak kaki. Transformasi yang dimaksudkan di sini adalah translasi (pergeseran), refleksi (pencerminan), rotasi (perputaran), dan refleksi-glide (pencerminan geser).

Selain pola berulang yang teratur, pola tersebut mempunyai sifat simetris. Garis yang digabungkan menjadi bujur sangkar, mempunyai sifat simetris, kanan dan kiri, atas dan bawah mempunyai ukuran yang simetris. Sama halnya juga dengan tapak kaki manusia, kanan dan kiri pasti simetris. Contoh lain yang mempunyai sifat simetris misalnya kupu-kupu, gunting, bahkan tubuh manusia pun bersifat simetris.

Dalam matematika, pola berulang dan simetris pada bidang datar, yang terbentuk dari transformasi, termasuk dalam grup simetri bidang datar dua dimensi. Grup simetri bidang datar ini sering disebut juga sebagai grup kristalografi bidang datar atau grup kertas dinding (wallpaper group). Fedorov (1891) merupakan orang yang pertama kali membuktikan bahwa hanya terdapat 17 kelompok berbeda pada grup simetri [1]. Keberadaan grup kertas dinding juga ditunjukkan dalam mosaik dan ornamen di istana Arab Alhambra, Spanyol [2], tempat-tempat bersejarah di Korea [3], maupun ornamen dan desain Islami [4].

Garnadi, dkk. [5] dalam penelitiannya telah melakukan survei terhadap pola grup kristalografi pada batik tradisional. Pengklasifikasian terhadap 272 pola batik telah dilakukan dan didapatkan 180 pola yang dikenali, menggunakan algoritma penentuan pola kertas dinding. Kartono, dkk. [6] dalam penelitiannya terhadap batik cap mengungkapkan bahwa pembuatan batik cap memerlukan biaya yang mahal. Oleh karenanya dibutuhkan suatu cara untuk menekan biaya tersebut, yaitu dengan membuat satu cap yang bisa menghasilkan beragam corak. Hal ini diselesaikan dengan menerapkan grup simetri dan kristalografi dua dimensi dan mampu menghasilkan beragam corak sebanyak 13 kain batik cap dari satu cap saja. 
Maulidya dan Sihombing [7] meneliti pola kristalografi yang terdapat pada batik Yogyakarta. Dari 65 pola yang diteliti, dapat diidentifikasi pola kristalografinya.

Dalam artikel ini dibahas bagaimana sebuah pola dasar dapat ditransformasi menjadi beragam pola yang lain menggunakan konsep kertas dinding bidang datar. Pola dasar tersebut dikenai operasi translasi, rotasi, refleksi, dan refleksi-glide sehingga dapat dibentuk pola lain yang lebih beragam. Selain itu, diambil beberapa motif dari internet untuk dibangkitkan menggunakan konsep grup kertas dinding ini. Penggabungan beberapa pola dasar dengan memanfaatkan beberapa grup juga dilakukan untuk membentuk pola baru. Hal ini dilakukan untuk memudahkan pembangkitan pola terutama untuk mendesain pola-pola pada keramik, motif kain, dan lain-lain.

\section{Kajian Pustaka}

\section{Grup Simetri}

Dalam ilmu matematika, khususnya struktur aljabar, terdapat istilah grup simetri yang merupakan hasil permutasi dari suatu himpunan berhingga. Salah satu aplikasi grup simetri dikenal dengan istilah kristalografi berdimensi dua atau tiga. Kristalografi merupakan ilmu yang mempelajari sifat-sifat geometri pada kristal. Konsep kristalografi ini kemudian dikembangkan untuk mempelajari sifat-sifat geometri pada bidang datar (dimensi dua), sehingga suatu bidang kosong dapat diisi oleh poligon yang kongruen tanpa tumpang tindih.

Jika poligon-poligon yang kongruen dan tidak tumpang tindih tersebut ditata dan memenuhi suatu bidang datar, maka bidang datar tersebut akan dipenuhi oleh salah satu dari bujur sangkar, segitiga, atau segi enam, seperti yang terlihat pada Gambar 1 [5]. Poligon-poligon tersebut dikenai transformasi, yang terdiri dari translasi, rotasi, refleksi, dan refleksi-glide sehingga bidang datar yang kosong tersebut dapat terisi penuh, tanpa ada lubang.

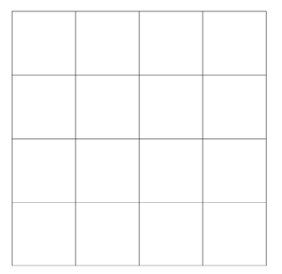

(a)

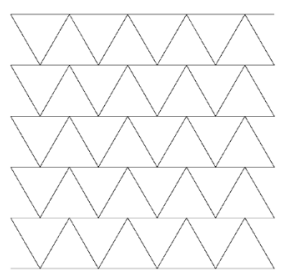

(b)

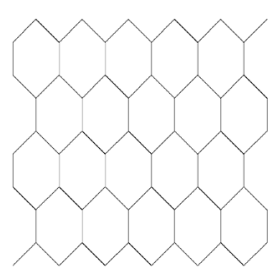

(c)

Gambar 1 Bidang datar yang diisi poligon (a) bujur sangkar, (b) segitiga, (c) segi enam 
Jenis transformasi yang digunakan dalam grup simetri beserta matriks transformasinya, dapat dijelaskan sebagai berikut. Jika diketahui bahwa $\left(\begin{array}{l}a \\ b\end{array}\right)$ adalah titik yang akan dikenai transformasi, maka:

- Translasi merupakan pergeseran dari satu posisi ke posisi lainnya sebesar $h$ satuan searah sumbu $x$ dan/atau sebesar $k$ satuan searah sumbu $y$. Matriks transformasi untuk translasi adalah $\left(\begin{array}{l}a^{\prime} \\ b^{\prime}\end{array}\right)=\left(\begin{array}{l}a+h \\ b+k\end{array}\right)$.

- Rotasi merupakan perputaran dengan sudut $\alpha$ tertentu. Matriks transformasi untuk rotasi dengan pusat $(0,0)$ adalah $\left(\begin{array}{l}a^{\prime} \\ b^{\prime}\end{array}\right)=\left(\begin{array}{cc}\cos \alpha & -\sin \alpha \\ \sin \alpha & \cos \alpha\end{array}\right)\left(\begin{array}{l}a \\ b\end{array}\right)$. Matriks transformasi untuk rotasi dengan pusat $(m, n)$ adalah $\left(\begin{array}{l}a^{\prime} \\ b^{\prime}\end{array}\right)=$ $\left(\begin{array}{cc}\cos \alpha & -\sin \alpha \\ \sin \alpha & \cos \alpha\end{array}\right)\left(\begin{array}{c}a-m \\ b-n\end{array}\right)+\left(\begin{array}{l}m \\ n\end{array}\right)$.

- Refleksi merupakan pencerminan terhadap suatu garis. Matriks transformasi refleksi terhadap garis $x=0(\operatorname{sumbu} x)$ adalah $\left(\begin{array}{l}a^{\prime} \\ b^{\prime}\end{array}\right)=\left(\begin{array}{cc}1 & 0 \\ 0 & -1\end{array}\right)\left(\begin{array}{l}a \\ b\end{array}\right)$. Matriks transformasi untuk refleksi terhadap garis $x=h$ adalah $\left(\begin{array}{c}a^{\prime} \\ b^{\prime}\end{array}\right)=\left(\begin{array}{c}2 h \\ 0\end{array}\right)-$ $\left(\begin{array}{ll}1 & 0 \\ 0 & 1\end{array}\right)\left(\begin{array}{l}a \\ b\end{array}\right)$. Matriks transformasi untuk refleksi terhadap garis $y=0$ (sumbu y) adalah $\left(\begin{array}{l}a^{\prime} \\ b^{\prime}\end{array}\right)=\left(\begin{array}{cc}-1 & 0 \\ 0 & 1\end{array}\right)\left(\begin{array}{l}a \\ b\end{array}\right)$. Matriks transformasi untuk refleksi terhadap garis $y=k$ adalah $\left(\begin{array}{c}a^{\prime} \\ b^{\prime}\end{array}\right)=\left(\begin{array}{c}0 \\ 2 k\end{array}\right)-\left(\begin{array}{ll}1 & 0 \\ 0 & 1\end{array}\right)\left(\begin{array}{l}a \\ b\end{array}\right)$.

- Refleksi-glide merupakan refleksi yang dilanjutkan dengan translasi, sejajar dengan sumbu refleksi.

\section{Grup Kertas Dinding}

Grup simetri yang diaplikasikan dengan konsep kristalografi dimensi dua ini dinamakan grup kertas dinding. Terdapat 17 grup kertas dinding, seperti yang terdapat pada Tabel 1. Poligon terkecilnya disebut sebagai kisi satuan (lattice).

Tabel 117 grup kertas dinding [1]

\begin{tabular}{cccccc}
\hline Grup & Notasi & $\begin{array}{c}\text { Tipe kisi } \\
\text { satuan }\end{array}$ & Rotasi & $\begin{array}{c}\text { Sumbu } \\
\text { refleksi }\end{array}$ & $\begin{array}{c}\text { Refleksi- } \\
\text { glide }\end{array}$ \\
\hline 1 & $p 1$ & Jajaran genjang & Tidak ada & Tidak ada & Tidak ada \\
2 & $p 2$ & Jajaran genjang & Orde $2\left(180^{\circ}\right)$ & Tidak ada & Tidak ada \\
3 & $p m$ & $\begin{array}{c}\text { Persegi } \\
\text { panjang }\end{array}$ & Tidak ada & Paralel & Tidak ada
\end{tabular}




\begin{tabular}{|c|c|c|c|c|c|}
\hline Grup & Notasi & $\begin{array}{c}\text { Tipe kisi } \\
\text { satuan }\end{array}$ & Rotasi & $\begin{array}{l}\text { Sumbu } \\
\text { refleksi }\end{array}$ & $\begin{array}{l}\text { Refleksi- } \\
\text { glide }\end{array}$ \\
\hline 4 & $p g$ & $\begin{array}{l}\text { Persegi } \\
\text { panjang }\end{array}$ & Tidak ada & Tidak ada & Ada \\
\hline 5 & $\mathrm{~cm}$ & Belah ketupat & Tidak ada & Paralel & Ada \\
\hline 6 & pmm & $\begin{array}{l}\text { Persegi } \\
\text { panjang }\end{array}$ & Orde $2\left(180^{\circ}\right)$ & Tegak lurus & Tidak ada \\
\hline 7 & $p m g$ & $\begin{array}{l}\text { Persegi } \\
\text { panjang }\end{array}$ & Orde $2\left(180^{\circ}\right)$ & Paralel & Ada \\
\hline 8 & $p g g$ & $\begin{array}{l}\text { Persegi } \\
\text { panjang }\end{array}$ & Orde $2\left(180^{\circ}\right)$ & Tidak ada & Ada \\
\hline 9 & $\mathrm{cmm}$ & Belah ketupat & Orde $2\left(180^{\circ}\right)$ & Tegak lurus & Tidak ada \\
\hline 10 & $p 4$ & Bujur sangkar & Orde $4\left(90^{\circ}\right)$ & Tidak ada & Tidak ada \\
\hline 11 & $p 4 m$ & Bujur sangkar & Orde $4+\left(90^{\circ}\right)$ & $45^{\circ}$ & Ada \\
\hline 12 & $p 4 g$ & Bujur sangkar & Orde $4^{*}\left(90^{\circ}\right)$ & $90^{\circ}$ & Ada \\
\hline 13 & $p 3$ & Heksagonal & Orde $3\left(120^{\circ}\right)$ & Tidak ada & Tidak ada \\
\hline 14 & p31m & Heksagonal & Orde $3 *\left(120^{\circ}\right)$ & $60^{\circ}$ & Ada \\
\hline 15 & $p 3 m 1$ & Heksagonal & Orde $3+\left(120^{\circ}\right)$ & $30^{\circ}$ & Ada \\
\hline 16 & $p 6$ & Heksagonal & Orde $6\left(60^{\circ}\right)$ & Tidak ada & Tidak ada \\
\hline 17 & $p 6 m$ & Heksagonal & Orde $6\left(60^{\circ}\right)$ & $30^{\circ}$ & Ada \\
\hline
\end{tabular}

Keterangan:

$+=$ pusat rotasi berada pada sumbu refleksi

* = tidak semua pusat rotasi berada pada sumbu refleksi

1. Grup $\boldsymbol{p 1}$, merupakan grup simetri paling sederhana karena hanya terdiri dari translasi, tanpa ada rotasi, refleksi, maupun refleksi-glide.

2. Grup $\mathbf{p 2}$, merupakan pengembangan dari grup $p 1$ dengan melakukan rotasi sebesar $180^{\circ}$.

3. Grup pm, merupakan grup yang mengandung refleksi, tanpa ada rotasi dan refleksi-glide. Grup ini menggunakan refleksi yang sejajar dengan salah satu sumbu, sumbu $x$ atau sumbu $y$, tetapi tidak keduanya.

4. Grup pg, merupakan grup yang mengandung refleksi-glide, tanpa ada rotasi dan refleksi. Grup ini menggunakan refleksi yang sejajar dengan salah satu sumbu, sumbu $x$ atau sumbu $y$, tetapi tidak keduanya, dan selanjutnya ditranslasikan sesuai dengan sumbu refleksinya. 
5. Grup $\mathbf{c m}$, merupakan grup yang mengandung refleksi dan refleksi-glide, yang sumbu-sumbunya sejajar, tanpa ada rotasi.

6. Grup pmm, merupakan grup yang mengandung refleksi, dimana terdapat dua sumbu refleksi yang saling tegak lurus dan berpotongan, serta rotasi $180^{\circ}$.

7. Grup pmg, merupakan grup yang mengandung refleksi, refleksi-glide, dan rotasi $180^{\circ}$.

8. Grup pgg, merupakan grup yang mengandung refleksi-glide (terhadap dua sumbu) dan rotasi $180^{\circ}$, tanpa ada refleksi. Pusat rotasi tidak terletak pada sumbu refleksi

9. Grup $\mathbf{c m m}$, merupakan grup yang mengandung refleksi, dimana terdapat dua sumbu refleksi yang saling tegak lurus, dan rotasi $180^{\circ}$. Pusat rotasi tidak terletak pada sumbu refleksi.

10. Grup $\boldsymbol{p 4}$, merupakan grup paling sederhana yang mengandung rotasi $90^{\circ}$, tanpa ada rotasi dan refleksi-glide.

11. Grup $\mathbf{p 4 m}$, merupakan pengembangan grup $p 4$ dengan menambahkan refleksi terhadap empat sumbu (sesuai dengan garis tengah dan diagonal bujur sangkar) dan rotasi $90^{\circ}$. Semua pusat rotasi terletak pada sumbu refleksi.

12. Grup $\boldsymbol{p 4 g}$, merupakan pengembangan grup $p 4$ dengan menambahkan refleksi terhadap empat sumbu (sesuai dengan garis tengah dan diagonal bujur sangkar) dan rotasi $90^{\circ}$. Tidak semua pusat rotasi terletak pada sumbu refleksi.

13. Grup $\boldsymbol{p 3}$, merupakan grup paling sederhana yang mengandung rotasi $120^{\circ}$, tanpa ada rotasi dan refleksi-glide.

14. Grup p31 m, merupakan pengembangan grup p3 dengan menambahkan refleksi terhadap tiga sumbu (sesuai dengan garis tengah segitiga sama sisi) dan rotasi $120^{\circ}$. Tidak semua pusat rotasi terletak pada sumbu refleksi.

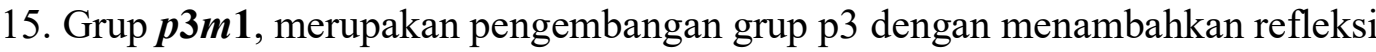
terhadap tiga sumbu (sesuai dengan garis tengah segitiga sama sisi) dan rotasi $120^{\circ}$. Semua pusat rotasi terletak pada sumbu refleksi.

16. Grup p6, merupakan grup yang mengandung rotasi $60^{\circ}$, tanpa ada rotasi dan refleksi-glide.

17. Grup $\mathbf{p 6 m}$, merupakan pengembangan grup $p 6$ dengan menambahkan refleksi terhadap enam sumbu (sesuai dengan garis tengah segi enam) dan rotasi $60^{\circ}$. Semua pusat rotasi terletak pada sumbu refleksi. 
Secara umum, notasi grup dinyatakan dengan empat karakter. Karakter pertama merupakan huruf $p$ atau $c$, dimana $p$ mempunyai arti sel primitif dan $c$ mempunyai arti sel terpusat (center). Karakter kedua merupakan angka, yang menyatakan order rotasi tertinggi. Karakter ketiga dan keempat merupakan huruf $m$ dan $g$, dimana $m$ mempunyai arti cermin (mirror), yang menyatakan ada tidaknya sumbu refleksi, dan $g$ mempunyai arti glide, yang menyatakan ada tidaknya refleksi-glide. Beberapa notasi ditulis dengan bentuk yang lebih sederhana, tidak ditulis lengkap dengan empat karakter, sebagai contoh: $p 2 m m$, yang disederhanakan menjadi pmm [8].

\section{Metode Penelitian}

Beberapa hal yang dilakukan dalam penelitian ini adalah: (1) menentukan dan membuat suatu pola dasar yang digunakan untuk membentuk pola lain, (2) membangkitkan 17 pola yang dibentuk dari 17 grup kertas dinding, dan (3) mengidentifikasi pola gambar yang diperoleh dari internet termasuk ke dalam grup kertas dinding. Crowe (2001) merumuskan algoritma yang dapat digunakan untuk mengidentifikasi 17 grup kertas dinding [9]:

1. Jika tidak ada rotasi, maka cek:

a. Jika ada refleksi, maka cek:

1) Jika ada refleksi glide di sumbu yang bukan merupakan sumbu refleksi, maka masuk dalam grup $\mathbf{c m}$.

2) Jika tidak ada refleksi glide di sumbu yang bukan merupakan sumbu refleksi, maka masuk dalam grup pm.

b. Jika tidak ada refleksi, maka cek:

1) Jika ada refleksi glide, maka masuk dalam grup pg.

2) Jika tidak ada refleksi glide, maka masuk dalam grup $\mathbf{p 1 .}$

2. Jika maksimum order rotasi $=2$, maka

a. Jika ada refleksi, maka cek:

1) Jika ada refleksi dua arah, maka cek:

a) Jika sumbu rotasi berada pada sumbu refleksi, maka masuk dalam grup pmm.

b) Jika sumbu rotasi tidak berada pada sumbu refleksi, maka masuk dalam grup $\mathbf{c m m}$.

2) Jika tidak ada refleksi dua arah, maka masuk dalam grup pmg.

b. Jika tidak ada refleksi, maka cek:

1) Jika ada refleksi-glide, maka masuk dalam grup pgg.

2) Jika tidak ada refleksi glide, maka masuk dalam grup $\boldsymbol{p 2}$.

3. Jika maksimum order rotasi $=3$, maka

a. Jika ada refleksi, maka cek: 
1) Jika sumbu rotasi berada pada sumbu refleksi, maka masuk dalam grup p3m1.

2) Jika sumbu rotasi tidak berada pada sumbu refleksi, maka masuk dalam grup p31m.

b. Jika tidak ada refleksi, maka masuk dalam grup $\boldsymbol{p 3}$.

4. Jika maksimum order rotasi $=4$, maka

a. Jika ada refleksi, maka cek:

1) Jika ada refleksi terhadap garis dengan sudut $45^{\circ}$, maka masuk dalam grup $p 4 m$.

2) Jika tidak ada refleksi terhadap garis dengan sudut $45^{\circ}$, maka masuk dalam grup $\mathbf{p 4 g}$.

b. Jika tidak ada refleksi, maka masuk dalam grup $p 4$.

5. Jika maksimum order rotasi $=6$, maka

a. Jika ada refleksi, maka masuk dalam grup p6m.

b. Jika tidak ada refleksi, maka masuk dalam grup p6.

\section{Hasil dan Pembahasan}

Pada artikel ini dibuat 17 pola yang dibentuk 17 grup kertas dinding, seperti terlihat pada Tabel 2, dengan pola dasar spiral seperti pada Gambar 2.

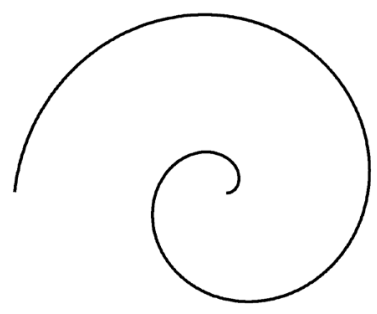

Gambar 2 Pola dasar spiral

Tabel 217 pola yang dibentuk dari 17 grup kertas dinding

\begin{tabular}{|c|c|c|c|}
\hline Notasi & Pola & Notasi & Pola \\
\hline$p 1$ & 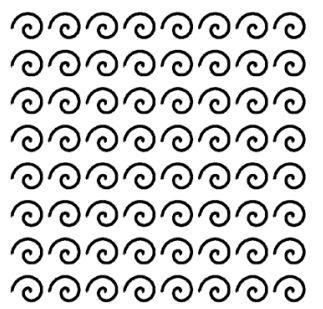 & $p 4$ & 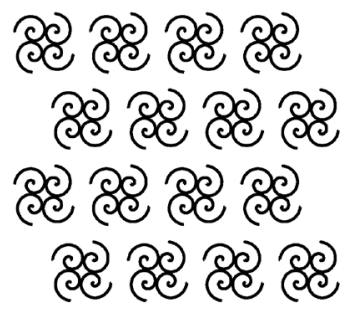 \\
\hline
\end{tabular}




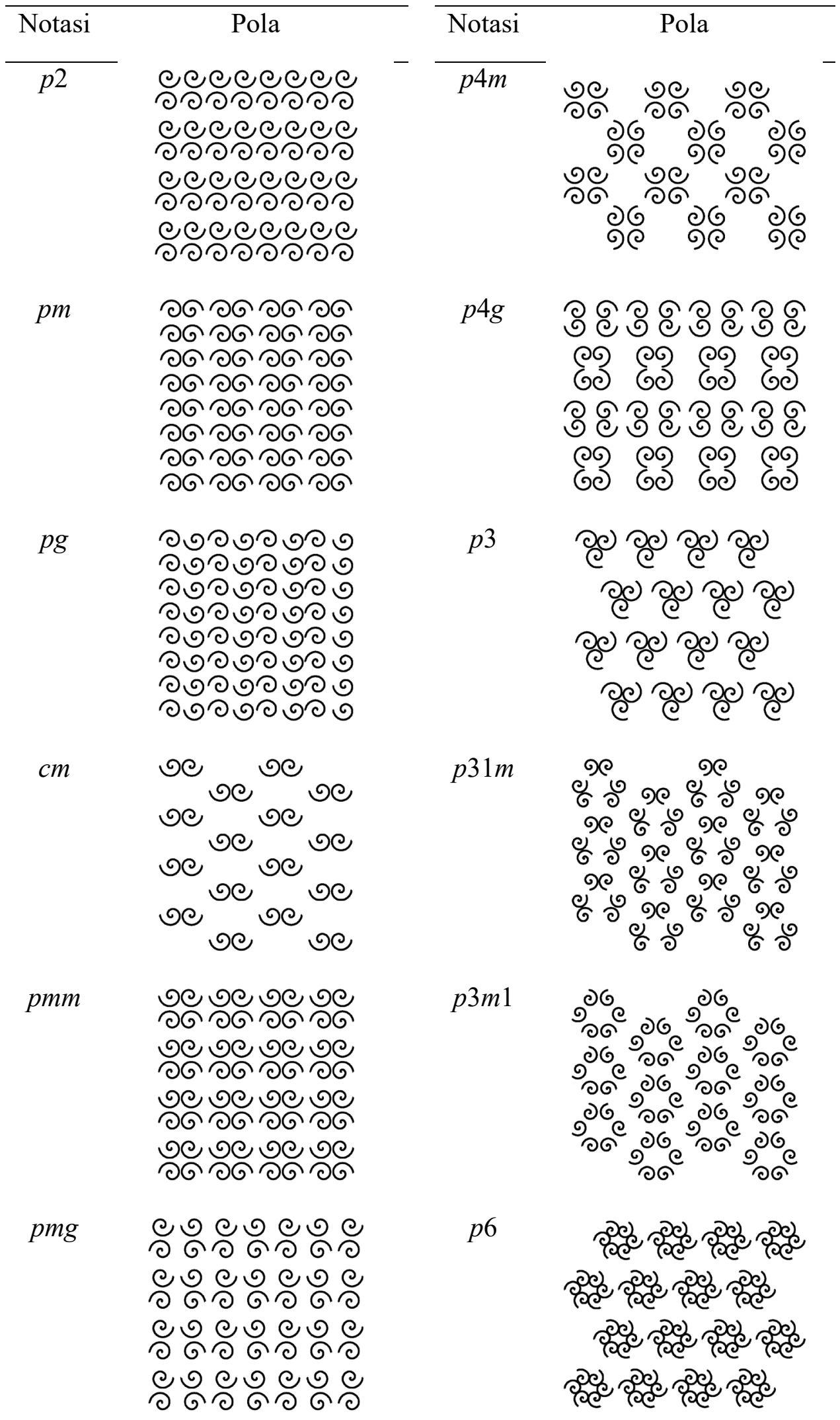




\begin{tabular}{|c|c|}
\hline Notasi & Pola \\
\hline$p g g$ & 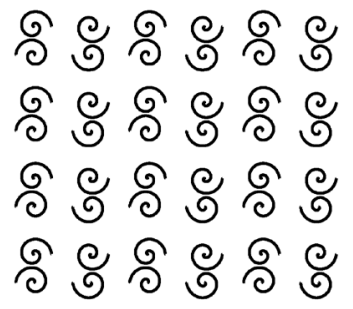 \\
\hline $\mathrm{cmm}$ & 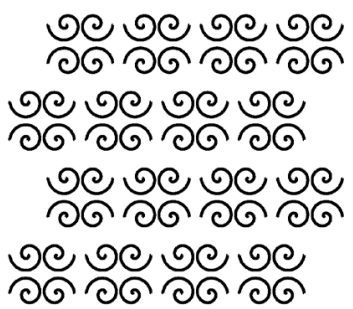 \\
\hline
\end{tabular}

Di samping pola-pola yang sudah dibentuk pada Tabel 2, beberapa pola juga bisa dibangkitkan dari grup kertas dinding tersebut. Tabel 3 memperlihatkan empat contoh motif yang diambil dari internet dan hasil digitalisasi yang diperoleh dari pembangkitan grup kertas dinding, dengan fokus pada bentuk spiralnya saja. Dengan pengidentifikasian pola grup kertas dinding yang telah dibahas pada bagian sebelumnya, motif-motif dari internet tersebut dapat dikenali sebagai salah satu dari 17 grup kertas dinding.

Tabel 3 Contoh motif dan hasil pembangkitan dari grup kertas dinding

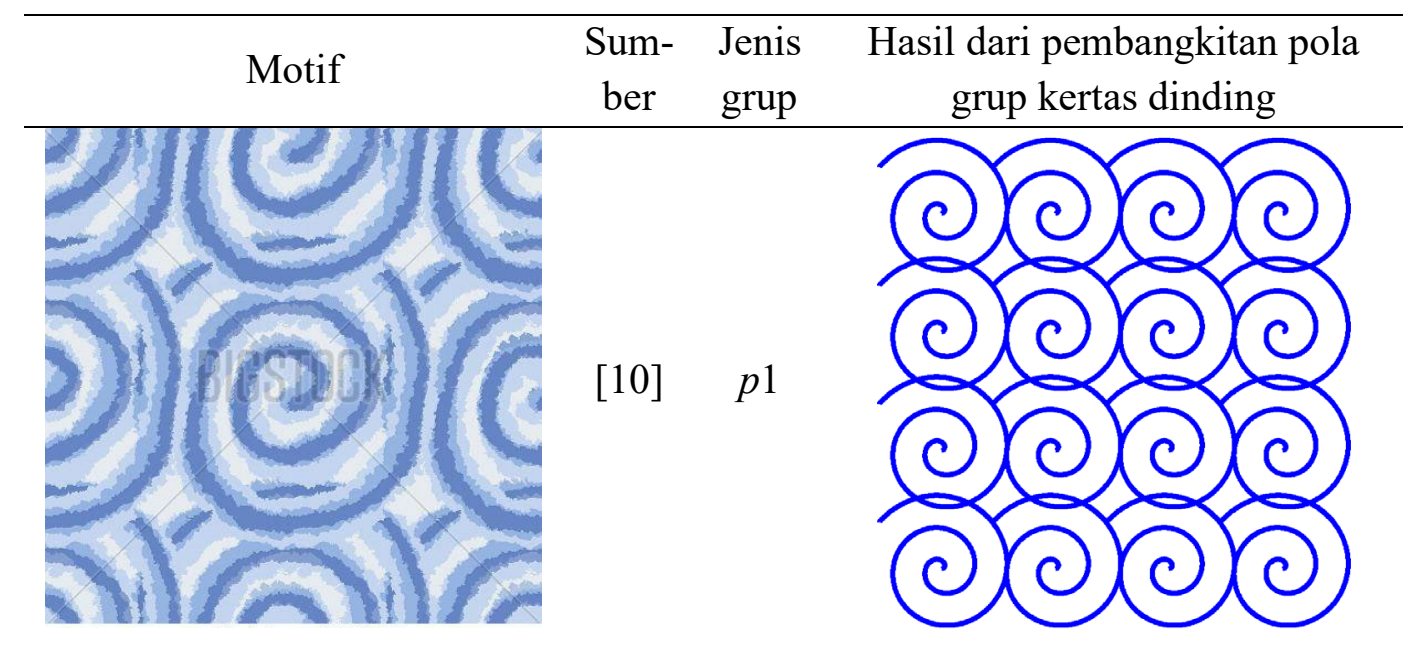




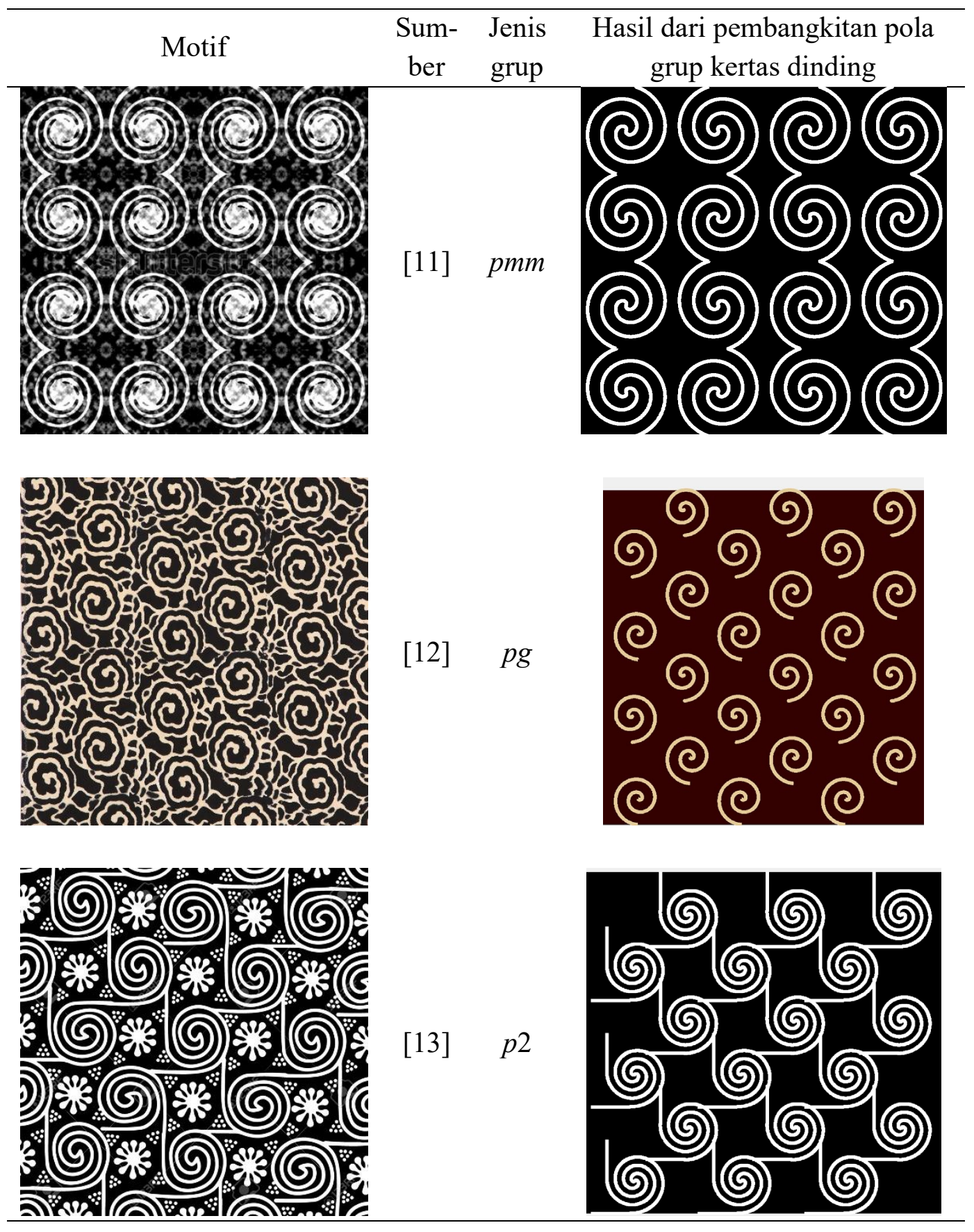

Keterangan:

1. Motif pertama [10] terbentuk dari suatu pola dasar yang berulang dengan translasi saja, sehingga motif tersebut termasuk dalam grup $p 1$. Rumus yang digunakan untuk membentuk pola tersebut adalah: $\left(\begin{array}{l}a^{\prime} \\ b^{\prime}\end{array}\right)=\left(\begin{array}{l}a+h \\ b+k\end{array}\right)$, dimana $\left(\begin{array}{l}a^{\prime} \\ b^{\prime}\end{array}\right)$ adalah titik hasil transformasi, $\left(\begin{array}{l}a \\ b\end{array}\right)$ adalah titik awal, $h$ adalah pergeseran sepanjang sumbu $x$, dan $k$ adalah pergeseran sepanjang sumbu $y$. 
2. Motif kedua [11] terbentuk dari suatu pola dasar yang berulang yang direfleksikan sejajar sumbu $x$ dan mempunyai rotasi $180^{\circ}$. Selain itu, motif ini juga mengandung refleksi-glide, sehingga termasuk dalam grup pmg. Beberapa rumus digunakan bersama yaitu $\left(\begin{array}{l}a^{\prime} \\ b^{\prime}\end{array}\right)=\left(\begin{array}{cc}1 & 0 \\ 0 & -1\end{array}\right)\left(\begin{array}{l}a \\ b\end{array}\right)$, untuk refleksi yang sejajar dengan sumbu $x,\left(\begin{array}{l}a^{\prime} \\ b^{\prime}\end{array}\right)=\left(\begin{array}{cc}\cos 180^{\circ} & -\sin 180^{\circ} \\ \sin 180^{\circ} & \cos 180^{\circ}\end{array}\right)\left(\begin{array}{l}a \\ b\end{array}\right)$, untuk rotasi order 2 , dan $\left(\begin{array}{l}a^{\prime} \\ b^{\prime}\end{array}\right)=\left(\begin{array}{cc}1 & 0 \\ 0 & -1\end{array}\right)\left(\begin{array}{l}a \\ b\end{array}\right)+\left(\begin{array}{l}h \\ 0\end{array}\right)$, untuk refleksi-glide, dimana $\left(\begin{array}{l}a^{\prime} \\ b^{\prime}\end{array}\right)$ adalah titik hasil transformasi, $\left(\begin{array}{l}a \\ b\end{array}\right)$ adalah titik awal, dan $h$ adalah pergeseran sepanjang sumbu $x$.

3. Motif ketiga [12] terbentuk dari suatu pola dasar yang berulang dengan mengaplikasikan refleksi-glide, sehingga motif tersebut termasuk dalam grup pg. Rumus yang digunakan untuk membentuk pola tersebut adalah $\left(\begin{array}{l}a^{\prime} \\ b^{\prime}\end{array}\right)=$ $\left(\begin{array}{cc}1 & 0 \\ 0 & -1\end{array}\right)\left(\begin{array}{l}a \\ b\end{array}\right)+\left(\begin{array}{l}h \\ 0\end{array}\right)$, dimana $\left(\begin{array}{l}a^{\prime} \\ b^{\prime}\end{array}\right)$ adalah titik hasil transformasi, $\left(\begin{array}{l}a \\ b\end{array}\right)+\left(\begin{array}{l}h \\ 0\end{array}\right)$ adalah titik awal, $h$ adalah pergeseran sepanjang sumbu $x$, dan $\left(\begin{array}{cc}1 & 0 \\ 0 & -1\end{array}\right)$ merupakan matriks transformasi untuk refleksi sejajar sumbu $x$.

4. Motif keempat [13] terbentuk dari suatu pola dasar yang berulang dengan merotasikan $180^{\circ}$, sehingga motif tersebut termasuk dalam grup $p 2$. Rumus yang digunakan adalah $\left(\begin{array}{l}a^{\prime} \\ b^{\prime}\end{array}\right)=\left(\begin{array}{cc}\cos 180^{\circ} & -\sin 180^{\circ} \\ \sin 180^{\circ} & \cos 180^{\circ}\end{array}\right)\left(\begin{array}{l}a \\ b\end{array}\right), \operatorname{dimana}\left(\begin{array}{l}a^{\prime} \\ b^{\prime}\end{array}\right)$ adalah titik hasil transformasi, $\left(\begin{array}{l}a \\ b\end{array}\right)$ adalah titik awal.

Selain pola dasar spiral yang telah dibahas sebelumnya, dapat digunakan juga pola dasar lain, seperti pada contoh berikut. Dalam contoh ini, digunakan dua pola dasar dengan menggabungkan tiga macam grup kertas dinding dari 17 grup kertas dinding yang ada, sehingga dihasilkan sebuah pola baru. Pembangkitan pola terdiri dari tiga langkah, yang dapat dilihat pada Tabel 4. Untuk pola pertama, digunakan pola pada Tabel 4 nomor 1 (kolom Pola dasar). Dengan memanfaatkan grup $\mathrm{cmm}$, dihasilkan pola seperti pada Tabel 4 nomor 1 (kolom Hasil). Pola kedua dibentuk dari pola dasar seperti pada Tabel 4 nomor 2 (kolom Pola dasar). Grup pmm digunakan untuk mendapatkan hasil seperti pada Tabel 4 nomor 2 (kolom Hasil). Selanjutnya pola pertama dan kedua digabungkan dengan memanfaatkan grup pm, sehingga didapat hasil seperti pada Tabel 4 nomor 3 (kolom Hasil).

Tabel 1. Tabel pembangkitan pola 


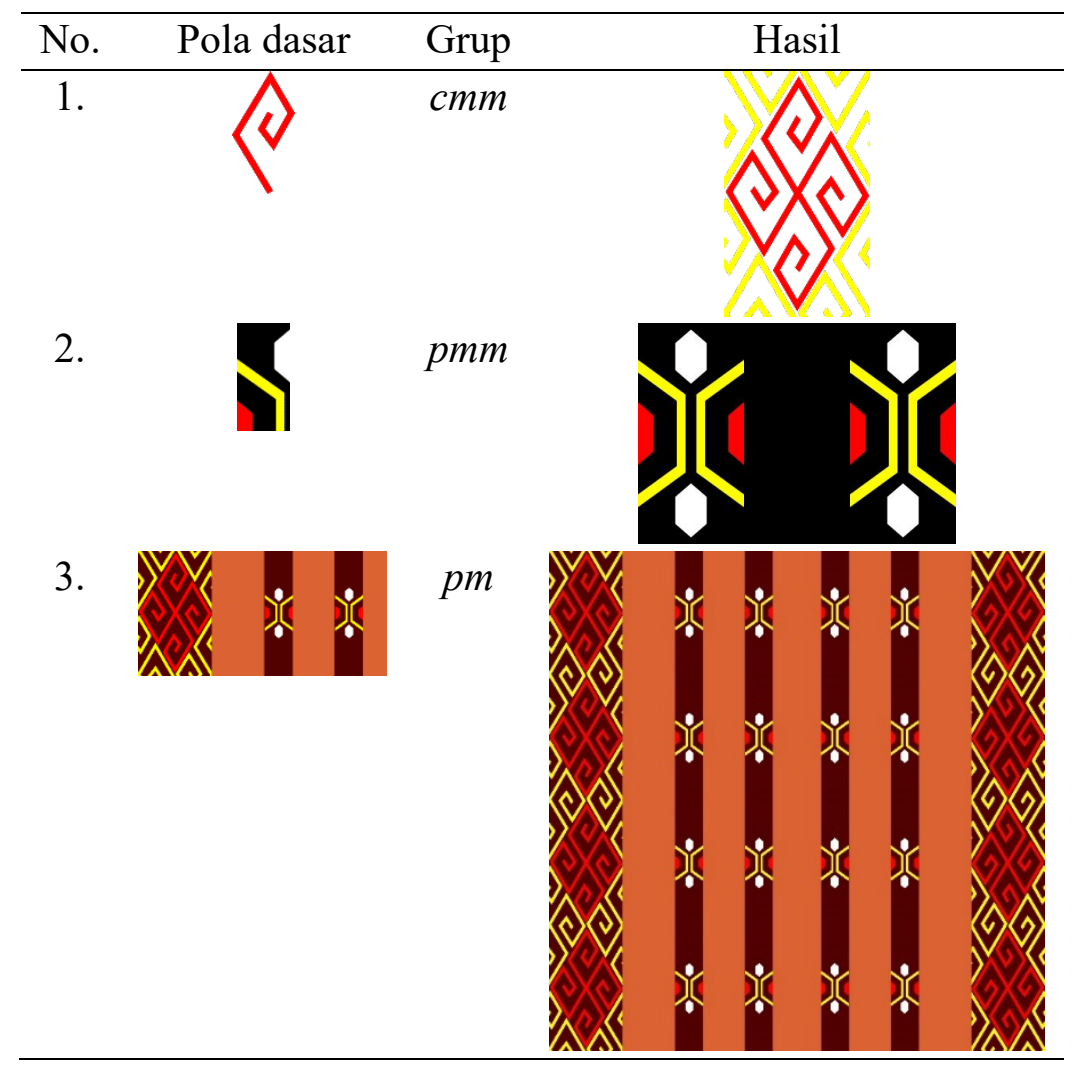

\section{Simpulan}

Berdasarkan hasil yang telah dibahas sebelumnya, grup kertas dinding dapat digunakan untuk menghasilkan motif berulang dan simetris pada kain, keramik, ornamen dinding, dan lain-lain. Motif tersebut dapat terdiri dari satu atau beberapa pola dasar dengan memanfaatkan satu atau beberapa grup kertas dinding. Penelitian selanjutnya diarahkan pada pembuatan motif dengan Graphical User Interface (GUI), sehingga pengguna dapat lebih mudah mendapatkan hasil digitalisasi pola dengan hanya memasukkan pola dasar ke aplikasi.

\section{Daftar Pustaka}

[1] EscherMath, "Wallpaper Patterns," November 2020. [Online]. Available: https://mathstat.slu.edu/escher/index.php/Wallpaper_Patterns.

[2] M. F. B. Blanco and L. N. d. C. Harris, "Symmetry Groups in the Alhambra," VisMath, vol. 13, no. 1, 2011.

[3] H. Shin, S. Sheen, H. Kwon and T. Mun, "Korean Traditional Patterns: Frieze and Wallpaper," Handbook of the Mathematics of the Arts and Sciences , pp. 1-16, 2018. 
[4] F. Albert, J. Gómis, J. Blasco, J. Valiente and N. Aleixos, "A new method to analyse mosaics based on Symmetry Group theory applied to Islamic Geometric Patterns," Computer Vision and Image Understanding, vol. 130, pp. 54-70, 2015.

[5] A. D. Garnadi, S. Guritman, A. Kusnanto and F. Hanum, "Survei Pola Grup Kristalografi Bidang Ragam Batik Tradisional," Jurnal Matematika dan Aplikasinya, vol. 11, no. 2, pp. 1-10, 2012.

[6] Kartono, R. H. S. Utomo and P. Sidik S., "Kristalografi Bidang Datar Batik Cap," in SNMPM Universitas Sebelas Maret, Solo, 2013.

[7] T. I. Maulidya and R. V. Sihombing, "Pola Kristalografi Bidang Ragam Batik di Yogyakarta," in Seminar Nasional Matematika dan Pendidikan Matematika, Purworejo, 2018.

[8] F. Hoffmann, Introduction to Crystallography, Switzerland: Springer, 2020.

[9] D. W. Crowe, "Symmetries of Culture," BRIDGES: Mathematical Connections in Art, Music, and Science, pp. 1-20, 2001.

[10] Krona100, "Vector tie dye seamless pattern. Batik spiral background.," [Online]. Available: https://www.bigstockphoto.com/image-294318625/stock-vector-vectortie-dye-seamless-pattern-batik-spiral-background. [Accessed November 2020].

[11] Hisyamrahman, "The beautiful of art Batik Pattern with connecting spiral concepts," November 2020. [Online]. Available: https://www.shutterstock.com/imageillustration/beautiful-art-batik-pattern-connecting-spiral-336228641.

[12] L. Corti, "Furniture Fabric Spiral Black White," November 2020. [Online]. Available: https://www.lisacorti.com/en/catalogue/11659/furniture-fabric-spiralblack-white/.

[13] T. Digital, "Vector - Spiral Batik Flower," November 2020. [Online]. Available: https://www.123rf.com/photo_85487838_stock-vector-spiral-batik-flower.html. 